\title{
Playful reflective thinking in a HyFlex classroom: using nostalgic games to engage students
}

\author{
Nayiri Keshishi \\ University of Surrey
}

Keywords: Hyflex classroom; nostalgia, playful learning, reflective thinking; social constructivism; Covid-19.

\section{The challenge}

Amidst the ever-changing government guidelines in response to the Covid-19 pandemic, universities have had to balance the safety of students and staff with attempting to maintain as much face-to-face teaching as possible. Consequently, a specific challenge some Learning Developers will have faced is the HyFlex classroom, a combination of students who are present in the physical classroom and those participating virtually (Columbia University, 2021). While some Institutions were operating in this way before the pandemic in order to offer students increased flexibility, I had not encountered this situation before when teaching the topic of reflection.

As with any form of teaching, my aim was to ensure all students were engaged and able to actively participate in class. This was especially important as those joining virtually had not chosen that form of participation and were only doing so due to either testing positive for Covid-19 or having to self-isolate. This contradicts some of the core values of the HyFlex model, including learner choice (Beatty, 2019). Therefore, I wanted to achieve a consistent student experience in which one group of participants did not feel disadvantaged over the other. I knew this would require experimentation, particularly when it came to the use of technology and designing activities which provided equivalent learning outcomes.

For the purposes of this compendium, I will focus on a reflective thinking activity designed for Foundation Year students. As part of their assessment, they were required to write a reflective journal discussing their personal and academic development. The intention was to support them in understanding the marking criteria and applying it to reflective writing 
examples. With some variations to the online version of the activity, I expected all students to be able to reflect, contribute ideas and interact with their peers.

\section{The response}

Playful learning has increased in popularity and is often used as a mechanism for improving engagement and motivation (Rivera and Garden, 2021). The nature of play, with its fundamental socially negotiated aspects, pushes it into social constructivism (Walsh, 2015). Though typically associated with children's education, it is a powerful method to integrate when providing students time in transitional learning spaces. It allows them to practise, apply and fully understand prior knowledge of key concepts; in this case reflective thinking (Piaget, 1962; Meyer and Land, 2006).

Inspired by Gillaspy (2020), I decided to experiment by incorporating a game built on origami fortune tellers. Those physically present were divided into pairs, given time to familiarise themselves with the marking criteria and read three reflective writing examples. Paper fortune teller templates were then shared (Figure 1), and students were given instructions on how to make, operate and play with the device. The hidden questions, revealed at the end of each round, linked to the reflective writing examples and used the same language as the marking criteria. Students were encouraged to discuss their answers, using the criteria to justify any comments or grades, where applicable. 
Figure 1. Fortune teller template used for reflective thinking activity.

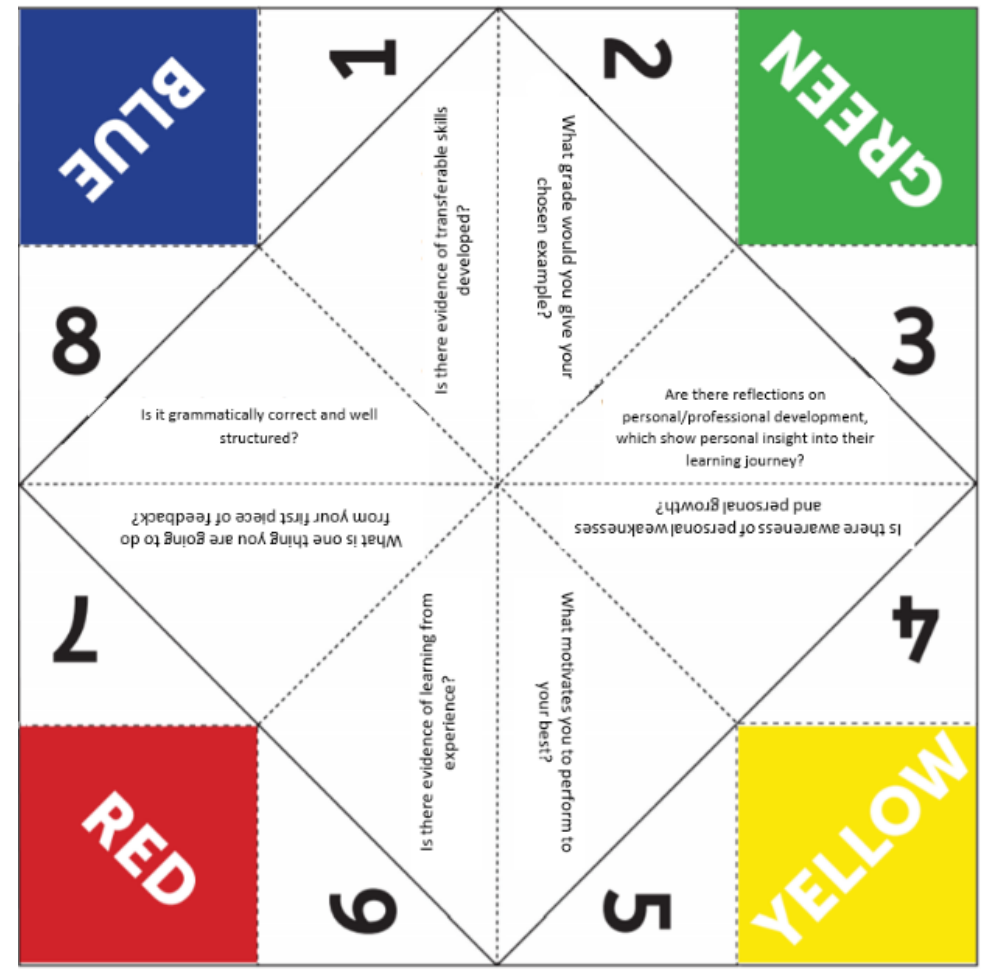

For students joining virtually, I enabled Zoom breakout rooms and chose to substitute the fortune teller with an online spinner created on Picker Wheel (2020). This mitigated issues of accessibility, such as access to a printer, and would still allow online students to playfully participate. It is also a practical way to deliver the activity fully online, if necessary.

The explicit playful elements of these games helped achieve a psychological acceptance of play, or 'lusory attitude' (Suits, 2005). As many of the students had encountered them before, it also brought a sense of childhood nostalgia to the classroom. This feeling of excitement and human connection is an important part of encouraging a playful environment. This is vital for a learning space — physical and/or virtual — to appear truly playful and for the activities to become meaningful (Nørgård et al., 2017).

In playing with reflective thinking, students were empowered in the process of constructing knowledge and applying it to the discussion of the reflective writing examples and later to their assessment (Rice, 2009). Despite the understandable limitations of anecdotal feedback, in-class comments and online chat responses revealed all participants enjoyed and connected with the activity. They felt it helped improve their reflective thinking/writing, 
especially in relation to satisfying the marking criteria. However, some virtual students also observed that it was difficult to create and maintain a dynamic dialogue with the physical classroom.

\section{Recommendations}

While there are still lessons to learn, this experience has highlighted viable ways of moving forward:

1) Plan - Allocate time for setting-up, engaging with both groups of students and providing clear instructions. For example, make sure you have written and visual guides on how to make the fortune teller, use the online spinner and play. Take time to also familiarise yourself with classroom technology, such as projectors, microphones, online breakout rooms and screen sharing.

2) Pedagogy - Design learning activities that promote active and playful learning. Use tools, like learning outcomes, to put agency in the hands of participants through structural invitations to play. This helps create a sense of belonging amongst students and builds an expectation that play is 'acceptable'. It also eases people into play by inviting and not forcing it (Walsh, 2015).

3) Engage - Provide guidelines on what technology features will be used and the options virtual students have to participate. Make materials such as slides, templates and links accessible on your VLE beforehand. This helps to minimise confusion and saves time (Bower et al., 2014). On reflection, I would incorporate discussion boards/collaborative documents to improve dialogue between physical and virtual students.

4) Support - Ideally, you would have two facilitators in the classroom, one to monitor the chat and address online questions and/or share contributions in real time. However, in the more likely scenario that you are teaching alone, consider asking physically present students to take on the role of chat monitor.

In conclusion, though we do not know if HyFlex classrooms will feature at our Institutions in the future, it is always worth considering how we can leverage technology and adjust our teaching to be more inclusive, engaging and playful. 


\section{References}

Beatty, B. J. (2019) Hybrid-Flexible Course Design. Available at:

https://edtechbooks.org/pdfs/mobile/hyflex/ hyflex.pdf (Accessed: 26 May 2021).

Bower, M., Kenney, J., Dalgarno, B., Lee, M.J.W. and Kennedy, G.E. (2014) 'Patterns and principles for blended synchronous learning: engaging remote and face-to-face learners in rich-media real-time collaborative activities'. Australasian journal of educational technology. 30(3), pp.261-272. Available at: https://doi.org/10.14742/ajet.1697 (Accessed: 22 July 2021).

Columbia University (2021) Hybrid/HyFlex Teaching \& Learning. Available at: https://ctl.columbia.edu/resources-and-technology/teaching-withtechnology/teaching-online/hyflex/ (Accessed: 25 May 2021).

Gillaspy, E. (2020) Make along live: experimenting with playful learning online. Available at: https://creativehecommunity.wordpress.com/2020/07/28/make-along-live/ (Accessed 24 November 2020).

Meyer, J. and Land, R. (2006) Overcoming barriers to student understanding: threshold concepts and troublesome knowledge. Florence: Routledge.

Nørgård, R.T., Toft-Nielsen, C. and Whitton, N. (2017) 'Playful learning in higher education: developing a signature pedagogy'. International journal of play. 6(3), pp.272-282. Available at: https://doi.org/10.1080/21594937.2017.1382997 (Accessed: 2 August 2021).

Piaget, J. (1962) Play, dreams, and imitation in childhood. New York: WW Norton.

Picker Wheel (2020) Available at: https://pickerwheel.com/ (Accessed: 24 November 2020). 
Rice, L. (2009) 'Playful learning'. The journal for education in the built environment. 4(2), pp.94-108. Available at: https://doi.org/10.11120/jebe.2009.04020094 (Accessed: 2 August 2021).

Rivera, E.S. and Garden, C.L.P. (2021) 'Gamification for student engagement: a framework'. Journal of further and higher education. pp.1-14. Available at: https://doi.org/10.1080/0309877X.2021.1875201 (Accessed: 2 August 2021).

Suits, B. (2005) The Grasshopper: games, life and utopia. Toronto: Broadview Press.

Walsh, A. (2015) 'Playful information literacy: play and information literacy in higher education'. Nordic Journal of Information Literacy in Higher Education. 7(1), pp.8094. Available at: https://doi.org/10.15845/noril.v7i1.223 (Accessed: 2 August 2021).

\section{Author details}

Nayiri Keshishi is a Teaching Fellow (Learning Development) at The University of Surrey. She has over seven years' experience in the design, development and delivery of engaging learning programmes and is currently teaching on the Foundation Year for both Psychology and Social Science. She has an MSc in Occupational and Business Psychology and is also an Associate Fellow of The Higher Education Academy. 